Bangladesh J. Bot. 41(1): 15-20, 2012 (June)

\title{
BACTERIAL LOAD IN RELATION TO PHYSICOCHEMICAL PARAMETERS AND PHYTOPLANKTON ABUNDANCE OF AN URBAN POND
}

\author{
Md Abdul Karim*, ZN Tahmida Begum and Md Sariful Islam \\ Department of Botany, University of Dhaka, Dhaka-1000, Bangladesh
}

Key words: Bacteria, Physicochemical parameters, Phytoplankton, Pond

\begin{abstract}
Abundance of bacteria and phytoplankton was studied in different months of an urban pond of Dhaka Metropolis from May 2009 to February 2010. Interrelationships among bacteria, phytoplankton densities and the physiochemical properties were also determined. The abundance of bacteria ranged from $5.9 \times 10^{3}$ to 1.5 $\times 10^{7} \mathrm{cfu} / 100 \mathrm{ml}$ and showed high densities between May and July, while the density of phytoplankton varied from $6.7 \times 10^{4}$ to $7.5 \times 10^{6}$ cells/l. Bacterial abundance showed a significant positive correlation with air and water temperature, while phytoplankton showed a significant negative correlation with both of them. Furthermore, bacteria showed a significant positive correlation with conductivity, TDS and alkalinity. Among the physicochemical variables water temperature was significantly correlated with air temperature, $\mathrm{pH}$ and alkalinity. Conductivity correlated significantly with TDS and alkalinity. With few exceptions there was inverse relationship between phytoplankton and bacterial abundance in the pond.
\end{abstract}

\section{Introduction}

Bacteria comprise a significant part of planktonic biomass and are responsible for contributing productivity and nutrient cycling in aquatic systems (Muylaert et al. 2002). They have fast growth rates and respond to low levels of pollutants as well as other physical, chemical and biotic environmental changes. From detection and effect perspectives, they provide sensitive, meaningful and quantifiable indications of ecological change (Paerl et al. 2003, Freese et al. 2006). Azam et al. (1983) reported that bacterioplankton play a fundamental role in the decomposition and mineralization of organic matter, as well as regeneration of mineral substances and production of biomass that is necessary for functioning of other organisms. Particularly in polluted waters rich in nutrients, bacterial biomass and production are high (Chróst and Siuda 2006) and heterotrophic bacteria then numerically dominate the abundance of bacterioplankton (Szeląg-Wasielewska and Stachnik 2010). Interaction between phototrophic and heterotrophic bacteria is important for the control of productivity in plankton, but these two parts of the community remain poorly characterized, especially in lowland eutrophic environments. A few studies are concerned with both the major groups of bacterioplankton at the same time, as most studies focus on one component: either phototrophic or heterotrophic bacteria (Sommaruga and Robarts 1997).

In Bangladesh, urban ponds play a significant role in meeting demands of water by the local inhabitants. Bathing, washing and sometimes water use for cooking and domestic cleansing are performed by pond water. But water quality standards for such water use are always neglected. A number of limnological studies has been carried out in the pond ecosystems of Dhaka Metropolis, but most of them lacking information on aquatic bacteria (Khondker and Chowdhury 1993, Sultana et al. 1999, Sultana and Khondker 2009a,b). So, the present study was undertaken to investigate the relationships among bacteria and phytoplankton density together with other physicochemical parameters in a pond of Dhaka Metropolis.

*Author for correspondence: <makarim10@yahoo.com> 


\section{Materials and Methods}

The study was carried out from May, 2009 to February, 2010 in Jahurul Haque Hall pond of Dhaka University Campus, which is situated within $23^{\circ} 43^{\prime} 41^{\prime \prime}$ to $23^{\circ} 43^{\prime} 45^{\prime \prime} \mathrm{N}$ and $90^{\circ} 23^{\prime} 18^{\prime \prime}$ to $90^{\circ} 23^{\prime} 23^{\prime \prime} \mathrm{E}$. The pond is perennial and more or less rectangular in shape. The area of the pond is about 1.05 ha having water depth $8-10 \mathrm{~m}$ with steep slopes. It has no out let or inlet and presently it is used for fish culture. Sampling was done in five different locations of the pond and the data were pooled to mean values for plotting.

Air and water temperature were measured at the time of sampling by a mercury thermometer, while, $\mathrm{pH}$, conductivity, TDS, alkalinity and DO were measured with the methodologies followed by Karim et al. (2010). Dilution plate and spread plate techniques were used for the enumeration and isolation of bacteria from the water sample in nutrient agar medium at $\mathrm{pH}$ 7.2. Inoculated plates were incubated at $37^{\circ} \mathrm{C}$. After $24 \mathrm{hr}$ of incubation, the plates having well discrete colonies grown on agar plates were selected for counting and the data were expressed as colony forming unit (cfu). Collection, preservation, qualitative and quantitative assessment of phytoplankton was done following the method of Sultana et al. (1999).

During the investigation a total of 20 measurements were carried out for each parameter and the data were used for Pearson's Correlation analysis to find the interrelationships among the variables.

\section{Results and Discussion}

The maximum air temperature $\left(32.5^{\circ} \mathrm{C}\right)$ was in June and the minimum $\left(16.0^{\circ} \mathrm{C}\right)$ was in January. In November there was a drop of air temperature to $25.5^{\circ} \mathrm{C}$ and it dropped to $22.25^{\circ} \mathrm{C}$ in December. Water temperature fluctuated a little and the mean values were almost lower than those of air temperature. The maximum water temperature $\left(31.25^{\circ} \mathrm{C}\right)$ was measured in June and the minimum $\left(19.38^{\circ} \mathrm{C}\right)$ was in January (Fig. 1). Similar observations have also been reported by other

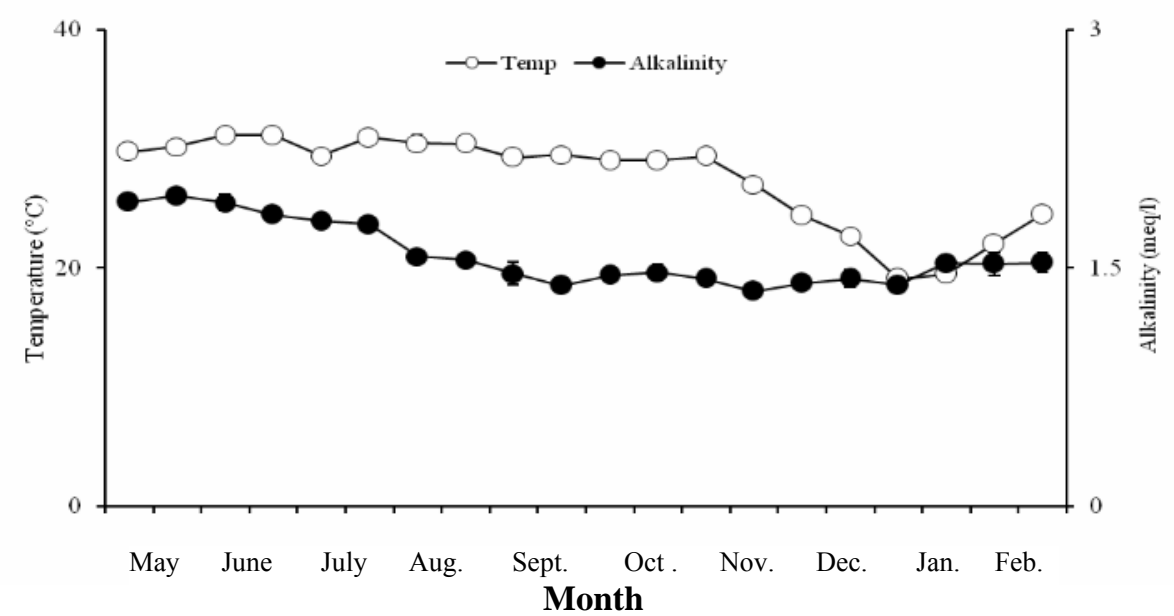

Fig. 1. Variation of water temperature and alkalinity in different months. Vertical bar indicates $\mathrm{SD}, \mathrm{n}=5$.

researchers in separate ponds (Oppenheimer et al. 1978, Begum and Alam 1987). The range of temperature mentioned above was found to be suitable for bacterial growth. Alkalinty was high between May and July but declined a little and remained unchanged for rest of the study period (Fig. 1). The conductivity of the pond water was high during early May to late June and remained 
almost unchanged for rest of the period (Fig. 2). However, a small rise of this parameter was seen in late July and late September with an almost similar trend for conductivity also (Fig. 2). From the beginning of the study the pond water showed a high $\mathrm{pH}$ in early June, it however remained almost similar between late June and late November (Fig. 3). The $\mathrm{pH}$ started increasing and reached another high value in late January and fell again till end February (Fig. 3). Throughout the study period, the concentration of dissolved oxygen (DO) showed two high concentrations one in

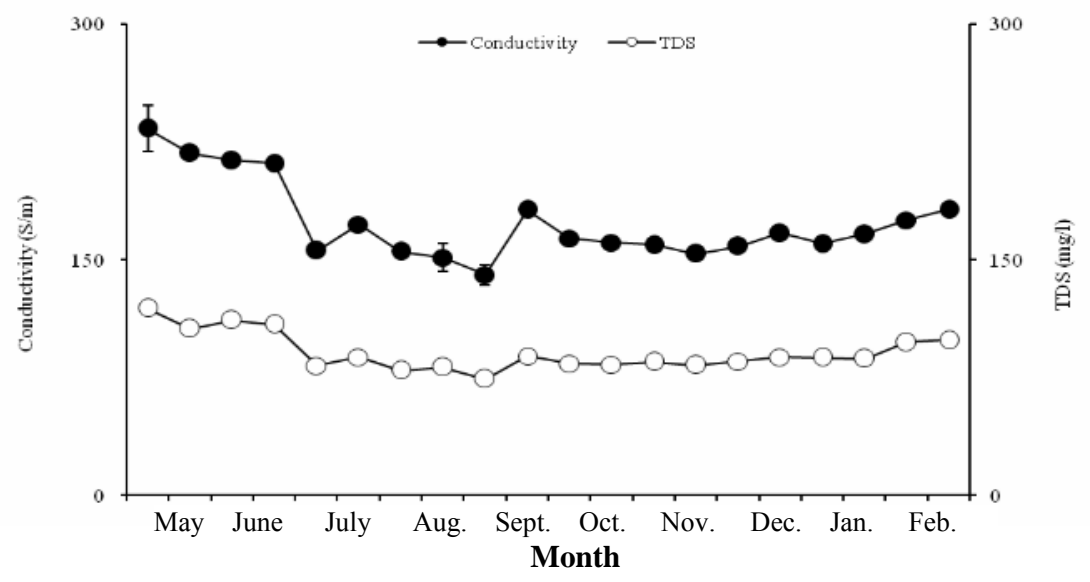

Fig. 2. Fluctuation in the conductivity of water and TDS in different months. Vertical bar indicates $\mathrm{SD}, \mathrm{n}=5$.

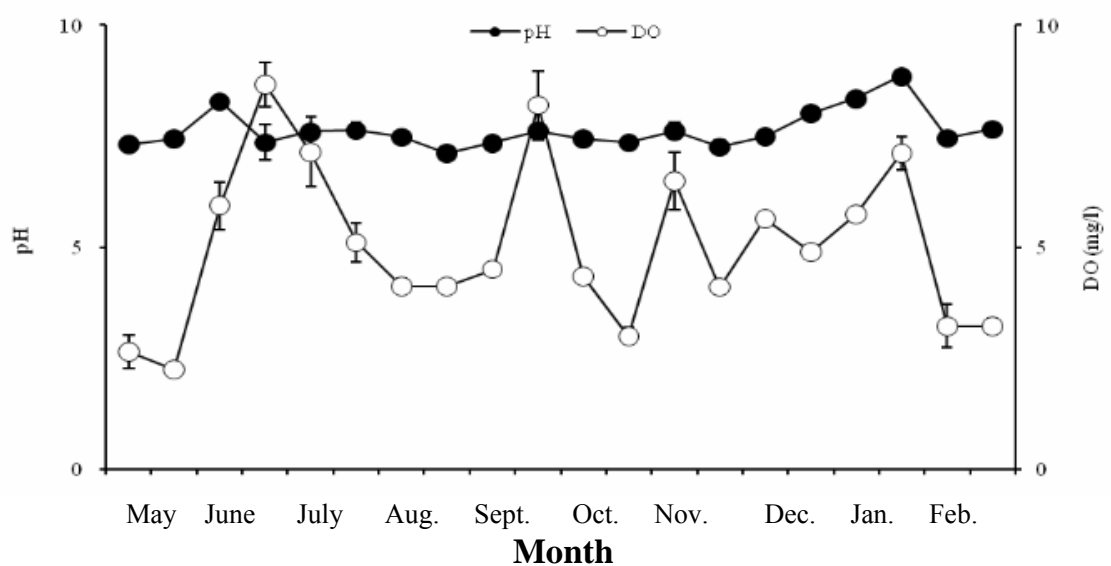

Fig. 3. $\mathrm{pH}$ and dissolved oxygen (DO) concentration of water in different months. Vertical bar indicates $\mathrm{SD}, \mathrm{n}=5$.

late June and another in late September (Fig. 3). Another two high concentrations of DO but at a little lower ranged than the previous one were also recorded in early November and late January (Fig. 3). During rainy months (between July and September), a gradual fall in the concentration of DO was observed. The dilution effect in the volume of pond water due to rainfall might be the reason for it (Fig. 3). 
The bacterial abundance (cfu) in the pond water ranged between $5.9 \times 10^{3}$ and $1.5 \times 10^{7}$ $\mathrm{cfu} / 100 \mathrm{ml}$. It was higher in early May, which started falling from late May and reached at a lowest value in late June (Fig. 4). For rest of the period, the bacterial abundance remained almost unchanged except a short peak in early January (Fig. 4). It occurred because of a high bacterial count obtained from the samples of southwestern part of the pond. Water of this site was contaminated by the inflow from the nearby residents. An occasional rainfall in November lowered the bacterial count with a high concentration of DO (Figs 3, 4). The heterotrophic bacterial count of the present study was similar to the findings of Saha et al. (2009).

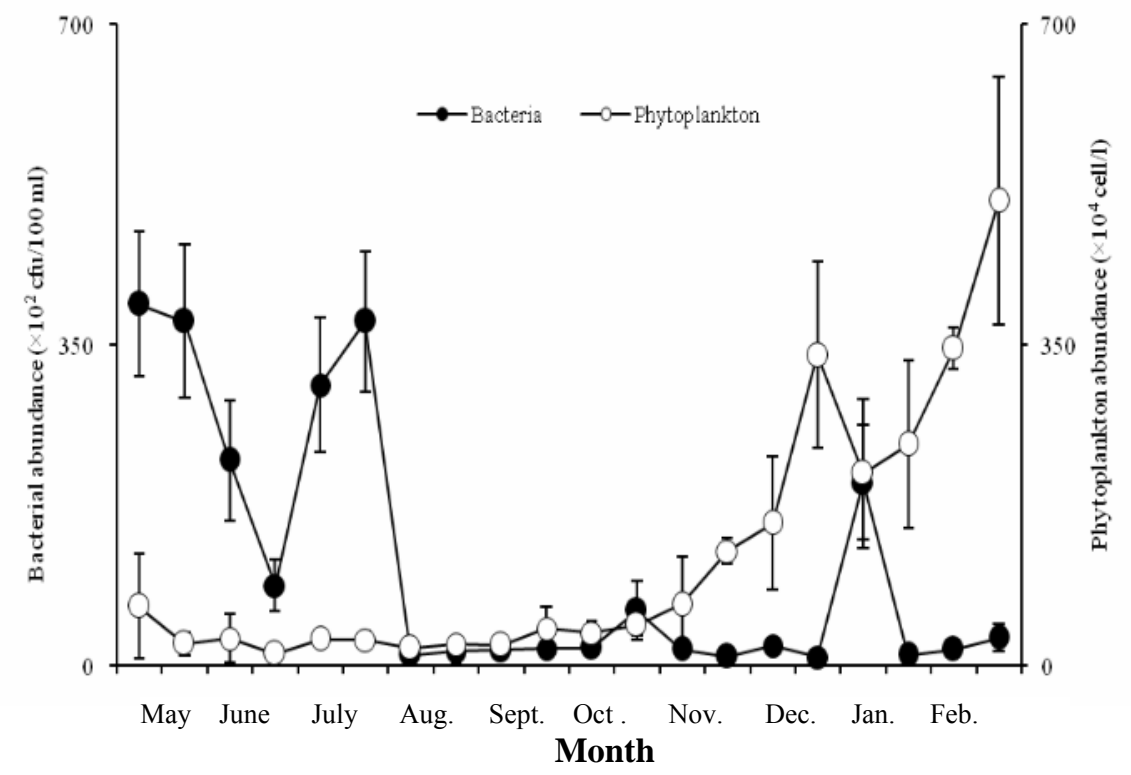

Fig. 4. Abundance of bacteria and phytoplankton in different months Vertical bar indicates SD, $\mathrm{n}=5$.

The highest count of total phytoplankton was recorded in late February (Fig. 4). This was due to the predominance of dinoflagellate group of phytoplankton from late November to late February i.e., in winter season (Fig. 4). Govind (1963) also observed higher abundance of phytoplankton in winter. With a few exceptions the bacterial abundance was inversely related to the phytoplankton abundance (Fig. 4). Observation of lower count of total phytoplankton in June was more or less similar to the results reported earlier in a pond at Bakerganj, Bangladesh (Alfasane 2002).

The matrix of product moment correlation among nine different variables has been presented in Table 1. Bacteria (cfu) showed a significant positive correlation with air temperature, water temperature, conductivity, TDS and alkalinity. But, phytoplankton showed a significant negative correlation with air temperature and water temperature and a significant positive correlation with $\mathrm{pH}$ with few exceptions. Among the physicochemical variables water temperature was significantly correlated with air temperature, $\mathrm{pH}$ and alkalinity. Conductivity correlated significantly with TDS and alkalinity. The result of correlation study shows that the bacterial abundance increases with an increase in air and water temperature, conductivity, TDS and alkalinity. However, phytoplankton abundance decreases with an increase in air and water temperature. 
Table 1. Matrix of production moment correlation coefficient (r) among different physicochemical and biological variables.

\begin{tabular}{llccccccccc}
\hline & Air temp. & $\begin{array}{c}\text { Water } \\
\text { temp. }\end{array}$ & $\mathrm{pH}$ & $\begin{array}{c}\text { Conduc- } \\
\text { tivity }\end{array}$ & TDS & $\begin{array}{c}\text { Alka- } \\
\text { linity }\end{array}$ & DO & $\begin{array}{c}\text { Phyto- } \\
\text { plankton }\end{array}$ & $\begin{array}{c}\text { Bac- } \\
\text { teria }\end{array}$ \\
\hline Air temp. & Pearson correlation & 1 & $0.960^{* *}$ & $-0.549^{* *}$ & 0.332 & 0.211 & $0.574^{* *}$ & -0.017 & $-0.724^{* *}$ & $0.460^{*}$ \\
& Sig. (2-tailed) & & 0.000 & 0.012 & 0.153 & 0.372 & 0.008 & 0.943 & 0.000 & 0.041 \\
Water & Pearson correlation & $0.960^{* *}$ & 1 & $-0.606^{* *}$ & 0.282 & 0.153 & $0.518^{*}$ & -0.029 & $-0.790^{* *}$ & $0.456^{*}$ \\
temp. & Sig. (2-tailed) & 0.000 & & 0.005 & 0.228 & 0.519 & 0.019 & 0.903 & 0.000 & 0.043 \\
pH & Pearson correlation & $-0.549^{*}$ & $-0.606^{* *}$ & 1 & 0.024 & 0.061 & -0.041 & 0.387 & 0.363 & -0.083 \\
& Sig. (2-tailed) & 0.012 & 0.005 & & 0.922 & 0.800 & 0.863 & 0.092 & 0.116 & 0.729 \\
Conduc- & Pearson correlation & 0.332 & 0.282 & 0.024 & 1 & $0.971^{* *}$ & $0.762^{* *}$ & -0.083 & -0.076 & $0.620^{* *}$ \\
tivity & Sig. (2-tailed) & 0.153 & 0.228 & 0.922 & & 0.000 & 0.000 & 0.729 & 0.749 & 0.004 \\
TDS & Pearson correlation & 0.211 & 0.153 & 0.061 & $0.971^{* *}$ & 1 & $0.720^{* *}$ & -0.107 & 0.073 & $0.554^{*}$ \\
& Sig. (2-tailed) & 0.372 & 0.519 & 0.800 & 0.000 & & 0.000 & 0.655 & 0.759 & 0.011 \\
Alkalinity & Pearson correlation & $0.574^{* *}$ & $0.518^{*}$ & -0.041 & $0.762^{* *}$ & $0.720^{* *}$ & 1 & -0.070 & -0.358 & $0.857^{* *}$ \\
& Sig. (2-tailed) & 0.008 & 0.019 & 0.863 & 0.000 & 0.000 & & 0.770 & 0.122 & 0.000 \\
DO & Pearson correlation & -0.017 & -0.029 & 0.387 & -0.083 & -0.107 & -0.070 & 1 & -0.195 & -0.181 \\
& Sig. (2-tailed) & 0.943 & 0.903 & 0.092 & 0.729 & 0.655 & 0.770 & & 0.410 & 0.444 \\
Phyto- & Pearson correlation & $-0.724^{* *}$ & $-0.790^{* *}$ & 0.363 & -0.076 & 0.073 & -0.358 & -0.195 & 1 & -0.365 \\
plankton & Sig. (2-tailed) & 0.000 & 0.000 & 0.116 & 0.749 & 0.759 & 0.122 & 0.410 & & 0.114 \\
Bacteria & Pearson correlation & $0.460^{*}$ & $0.456^{*}$ & -0.083 & $0.620^{* *}$ & $0.554^{*}$ & $0.857^{* *}$ & -0.181 & -0.365 & 1 \\
& Sig. (2-tailed) & 0.041 & 0.043 & 0.729 & 0.004 & 0.011 & 0.000 & 0.444 & 0.114 & \\
\hline
\end{tabular}

$*$ and $* *$ indicate significant correlation at 0.05 and 0.01 level, respectively. $\mathrm{N}=20$.

The load of aerobic heterotrophic bacteria clearly shows a significant level of microbial pollution in the pond. In this study, the inverse relationship between bacterial and phytoplankton could be explained in a way that the excretion of organic compounds from the phytoplankton primary production stimulated the growth of bacteria (Bratbak and Thingstad 1985). In the whole system, the dilution caused by rainwater and the incoming pollutants from the nearby sources also affected the water quality of the pond.

\section{References}

Alfasane MA, MS Islam and ZNT Begum 2002. Association of Vibrio cholerae 01 and 0139 with phytoplankton in a pond of Bangladesh. Bangladesh J. Bot. 31(1): 19-22.

Azam F, T Fenchel, JG Field, JS Gray, LA Meyerr-Reil and F Thingstad 1983. The ecological role of water column microbes in the sea. Mar. Ecol. Prog. Ser. 10: 257-263.

Begum ZNT and MJ Alam 1987. Plankton abundance in relation to physico-chemical variables in two ponds in Maijdee Court, Noakhali. J. Asiat. Soc. Bangladesh, Sci. 13(1): 55-63.

Bratbak G and TF Thingstad 1985. Phytoplankton-bacteria interactions: an apparent paradox? Analysis of a model system with both competition and commensalism. Mar. Ecol. Prog. Ser. 25: 23-30.

Chróst RJ and W Siuda 2006. Microbial production, utilization, and enzymatic degradation of organic matter in the upper trophogenic layer in the pelagial zone of lakes along a eutrophication gradient. Limnol. Oceanogr. 51: 749-762.

Freese HM, U Karsten and R Schumann 2006. Bacterial abundance, activity, and viability in the eutrophic river Warnow, northeast Germany. Microb. Ecol. 51 (1): 117-127. 
Govind BV 1963. Preliminary studies on plankton of the Tungabhadra reservoir. Indian. J. Fish X (1A): 148153.

Karim MA, ZNT Begum, SM Ullah and MS Islam 2010. Bacteriological and physicochemical analysis of pond in Dhaka. J. NOAMI. 27: 59-67.

Khondker M and SA Chowdhury 1993. Relationships of phytoplankton biomass to some water quality parameters in a mesotrophic pond. Dhaka Univ. J. Biol. Sci. 2: 87-92.

Muylaert K, K Van der Gucht and N Vloemans 2002. Relationship between bacterial community composition and bottom-up versus top-down variables in four eutrophic shallow lakes. Appl. Environ. Microb. 68(10): 4740-50.

Oppenheimer JR, MG Ahmed, A Huq, KA Haque, AKMA Alam, KMS Aziz, S Ali and ASMM Haque 1978. Limnological studies of three ponds in Dhaka. Bangladesh J. Fish. 1(1): 1-28.

Paerl HW, J Dyble and PH Moisander 2003. Microbial indicators of aquatic ecosystem change: current applications to eutrophication studies. FEMS Microbiol. Ecol. 46: 233-246.

Saha ML, MR Khan, M Ali and S Hoque 2009. Bacterial load and chemical pollution level of the river Buriganga, Dhaka, Bangladesh. Bangladesh J. Bot. 38(1): 87-91.

Sommaruga R and RD Robarts 1997. The signifi cance of autotrophic and heterotrophic picoplankton in hypertrophic ecosystems. FEMS Microbiol. Ecol. 24: 187-200.

Sultana M, M Khondker and A Aziz 1999. Plankton composition and its seasonal dynamics in two urban ponds. Dhaka Univ. J. Biol. Sci. 8: 35-43.

Sultana M and M Khondker 2009a. Assessment of phytoplankton primary productivity of two urban pond ecosystems of Bangladesh. Dhaka Univ. J. Biol. Sci. 18(2): 127-135.

Sultana M and M Khondker 2009b. A comparative limnology of two urban pond ecosystems: Physical and chemical features. Bangladesh J. Asiat. Soc. Sci. 35(1): 65-71.

Szelag-Wasielewska E and W Stachnik 2010. Auto and heterotrophic picoplankton in a lowland river (Warta river, Poland) Ocean. Hydrob. Stud. 39(1): 137-146.

(Manuscript received on 5 March, 2011; revised on 27 May, 2012) 